\title{
Toward Common Values in Journalistic Ethics: Slander vs. Truthfulness from an Islamic Perspective
}

\author{
Christoph Marcinkowski*
}

Instances of blasphemy against Prophet Muhammad (peace be upon him) are perhaps the most dramatic exposures of recent date of the discrepancies between 'freedom of expression' and 'freedom of press' on the one hand, and 'journalistic ethics' on the other. ${ }^{1}$ Such episodes expose the dilemma in journalistic ethics between a particularly Western understanding of 'journalistic freedom' and the more universal right of protection of the public and individual persons alive or dead against slander and misinformation.

In what follows, the author shows how such dilemma and ambivalence can be overcome by recourse to the teachings of Islam, with its firm prohibition against slander, as well as the primacy of ethics linked with spirituality seen in the love of Muslims for the Prophet (p.b.u.h), which can then form the basis towards common values and understanding between Islamic and Western civilisations.

\section{Western Ambivalence}

Tension does exist between 'political freedom' - especially 'freedom of speech' - and certain examples of art, literature, speech or other acts considered by some to be sacrilegious or blasphemous. Such tension has not been resolved but has resulted in an ambivalence which is manifested in numerous instances of controversy and conflict around the world. Although many laws prohibiting blasphemy have long been repealed, particularly in 'the West', they remain in place in many other countries and jurisdictions.

In Western societies, on the one hand, legislation based on 'blasphemy' would be irreconcilable with their secular values. Thus protection of religious communities, their faiths and its symbols and major exponents would not be possible when basing legal cases on 'blasphemy'. On the other hand, in some cases such laws are still on the books, albeit no longer actively enforced. In fact, legislation in most Western countries does provide for the prosecution of insult and steering up racial hatred. Germany, in particular, has advanced legislation in this regard. It could even be invoked as a useful tool to protect the honour and dignity of individuals or groups.

The obviously ambivalent stance of the secular Western societies of today contrasts sharply with the clear position of Islam, which is so outspoken and strict when it comes to enjoining its followers to strive toward good manners ( $a d a b$ ) and refraining from untruthfulness. The very genre of Hadith-literature, which is unique by itself, bears witness to the efforts of the scholars of the Classical period 
of Islam toward veracity and accuracy of transmitted "news", i.e. the Sunnah of the Prophet (p.b.u.h).

\section{Slander in Islam}

What then is the stance of Qur'an and Sunnah on slander and can and should those two sources of Divine knowledge and wisdom also be relevant when entering an open discourse with the secular West in order to discuss contemporary ethics - in our present case in the media?

As a matter of fact, the Holy Qur'an is quite clear as to backbiting and slander. We read:

O ye who believe! Avoid suspicion as much (as possible): for suspicion in some cases is a sin: and spy not on each other nor speak ill of each other behind their backs. Would any of you like to eat the flesh of his dead brother? Nay ye would abhor it. But fear Allah, for Allah is OftReturning, Most Merciful (al-Hujurāt, 49:12).

This corresponds closely with a saying (hadith) of the Prophet (p.b.u.h) that "Backbiting implies your talking about your brother in a manner which he does not like." It was said to him: "What is your opinion about this that if I actually find (that failing) in my brother which I made a mention of?" He said: "If (that failing) is actually found (in him) by what you assert, you have in fact backbitten him, and if that is not in him it is a slander".

In Surat al-Tawbah, we find the following stern admonition:

Those who criticize the contributors among the believers concerning [their] charities and [criticize] the ones who find nothing [to spend] except their effort, so they ridicule them - Allah will ridicule them, and they will have a painful punishment (9:79).

In the authoritative collections of hadith-such as cited below from Abu Dawud - the believers are warned against slander, backbiting and untruthfulness in general:

The most prevalent kind of usury $[$ rib $\bar{a}]$ is going to lengths in talking unjustly against a Muslim's honour. ${ }^{2}$

Everything of a Muslim is sacred to a Muslim: his property, honor, and blood. It is enough evil for a man to despise his brother Muslim. ${ }^{3}$

Imām Mālik refers in his Muwatțā to the following hadith: "If the Lord should protect a man from the mischief of two things, he shall enter Paradise: firstly, from that which is between his two jaws [i.e. his tongue], and secondly, from that which is between his two loins". ${ }^{4}$ 
Famous Sufis and Friends of Allāh ( $a w l i y \bar{a}$ ') have always taken a strong stance against slander. Al-Qushayrī reports the following in his Risālah:

Sufyān ibn al-Husayn reported, "I was sitting with Iyas ibn Mu'āwiya, and I slandered a man. He asked me, 'Have you attacked the Byzantines or the Turks this year?' I replied, 'No'. He exclaimed, 'The Turks and the Byzantines are safe from you while your Muslim brother is not!'",5

All the schools of Islamic jurisprudence prescribe stern punishments for slander and false accusations of any kind as they have a very negative effect on the stability of the Muslim community as a whole. ${ }^{6}$ The famous Hadrami sage Imam 'Abdallah al-Haddad was once asked why slander and backbiting is worse than thirty adultery offenses although it was not considered by scholars to be a major sin as adultery. Imam al-Haddad answered:

The motive behind adultery [is] merely lust which is a bestial attribute.

While the motive behind backbiting and dishonoring Muslims is malice in the heart and rancor and perfidy toward the (slandered) Muslim. These are demonic attributes and are up to thirty times worse and more loathsome than bestial attitudes (...). ${ }^{7}$

The reason behind quoting from the sources of Islam in such a detailed manner is obvious: because no faith or religious system other than Islam offers such a stern attitude when it comes to fact-oriented reporting and protecting one's honour against slander. This fact should therefore also be made the focal point when facing Western partners in discussions on journalistic ethics, freedom of the press and similar topics.

\section{Images of the Prophet}

What angered most Muslims in cases of blasphemy is not a depiction of the Prophet (p.b.u.h) as such, but rather his association with terrorism and violence - a misrepresentation from their point of view. Tariq Ramadan in his masterly interpretation of the life of the Prophet (p.b.u.h), conveys to us something of the meaning of the Prophet to Muslims all over the world:

The Prophet Muhammad occupies a particular place in the life and conscience of Muslims today, just as he did in the past... [He] received and transmitted the last revealed book, the Qur'an, which repeatedly insists on the eminent and singular position of the Messenger of God, all at once a prophet, a bearer of news, a model, and a guide. He was but a man, yet he acted to transform the world in the light of Revelation and inspirations he received from God, his Educator ( $a r-R a b b)$. That this man was chosen and inspired by God but also fully accepted his 
own humanity is what makes Muhammad an example and guide for the Muslim faithful. ${ }^{8}$

The late German professor Annemarie Schimmel wrote:

The personality of Muhammad is indeed, besides the Quran, the center of Muslims' life; the Prophet is the one who forever remains the "beautiful model" (Sura 33:21) for the life of all those who acknowledge in the profession of faith that he is truly "the messenger of God". 9

That the Prophet (pbuh) occupies such a central place in the heart of Muslims, coupled with the strict position of Islam on slander, explains why episodes of blasphemy continue to play out in Islamic and Western civilisational encounters.

\section{Conclusion: Spirituality, the Common Ground}

We can only hope that common sense and - above all - decency and mutual respect between civilisations will prevail also in the relations between the West and the world of Islam.

- We should also appreciate the true nature and purpose of morality and ethics, which is to please Him and to purify ourselves. The late Alija Izetbegovic, the first President of independent Bosnia-Herzegovina, summarised this line of thought very beautifully:

Moral conduct is either meaningless, or else, it has its meaning and sense in the existence of God. A third option is not possible. We should either discard morality as a heap of prejudices or introduce into the equation another value that we could call the figure of eternity, provided that life is eternal and that God as well as a world, different from the natural one, exists, in which man's moral conduct can be meaningful and justified. ${ }^{10}$

- The correct way to respond to slander is summarised here by Qadi 'Iyād, which, as a beautiful "by-product", contributes also to the above-mentioned purification of ourselves:

Forbearance, long-suffering, pardoning in spite of having the power to punish and patient endurance in affliction are distinct from each other. Forbearance ( $\mathrm{hilm}$ ) is a state of dignified bearing and constancy despite provocation. Long-suffering (ihtimāl) is self-restraint and resignation in the face of pains and injuries. Patience $(s a b r)$ is similar to it, but its meaning is slightly different. As for pardoning (' $a f w$ ), it is refusing to hold something against someone else. All of these qualities are part of the $a d a b$ with which Allāh endowed His Prophet. Allāh says: "Take 
the way of pardon and command the correct and turn away from the ignorant" (al-A'rāf 7:199). ${ }^{11}$

- This attitude should not only be the approach when facing untruthfulness, slander and non-fact-oriented reporting in the non-Muslim media, but perhaps above all, also among Muslims themselves. Ultimately this will contribute to a healthy climate of debating between people of different views.

\section{Notes}

* Christoph Marcinkowski (PhD ISTAC, Kuala Lumpur; MA, Free University Berlin) is a an independent German scholar in Islamic Studies based in Berlin. He had been Editor of this journal and Principal Research Fellow at IAIS from 2008 to 2012. The author of 12 books, he is currently also an External Fellow to the Middle East Institute (Washington DC, United States) and the Bahrain Institute of Banking and Finance. Previously, he had also been attached in various capacities to New York's Columbia University and to Singapore's Institute of Defense and Strategic Studies.

1. The theme has been briefly explored in Christoph Marcinkowski, "Journalistic Ethics and Freedom of Speech: Ideals and Realities," Islam and Civilisational Renewal, vol. 3 no. 2 (January 2012), pp. 377-82.

2. Abu Dāwud, Sunan., ed. M. M. 'Abd al-Hamīd, 4 vols. (Cairo: n.p, 1950), hadith no. 4858 .

3. Ibid., no. 4864.

4. Imam Malik, Al-Muwatta of Imam Malik ibn Anas: The First Formulation of Islamic Law, tr. Aisha Abdarrahman Bewley (Inverness (UK): Madinah Press, 2001), hadith no. 1794.

5. Al-Qushayrī, Principles of Sufism, tr. B. R. von Schlegel (New York: Oneonta, 1990), 106.

6. Ibn Rushd, The Distinguished Jurist's Primer (Bidayat al-Mujtahid wa Nihayat al-Muqtasid), tr. Imran Ahsan Khan Nyazee. 2 vols. (Reading (UK): Garnet Publishing, 1994), 2:533ff

7. Imam al-Haddād, The Sublime Treasures: Answers to Sufi Questions, tr. Mostafa al-Badawi (Louisville KY: Fons Vitae, 2008), 77-8.

8. Tariq Ramadan, In the Footsteps of the Prophet: Lessons from the Life of Muhammad (Oxford: Oxford University Press, 2007).

9. Annemarie Schimmel, And Muhammad is His Messenger: The Veneration of the Prophet in Islamic Piety (Chapel Hill NC: University of North Carolina Press, 1985).

10. Alija Izetbegovic, Islam between East and West (Petaling Jaya (Malaysia): Islamic Book Trust, 2010).

11. Qadi 'Iyād, Muhammad, Messenger of Allah: Ash-Shifa of Qadi 'Iyad, tr. Aisha Abdarrahman Bewley (Inverness (UK): Madinah Press, 1991), 54. 